\title{
Pretransplant Serum Hepatitis C Virus RNA Levels Predict Response to Antiviral Treatment after Living Donor Liver Transplantation
}

\author{
Yoshihide Ueda ${ }^{1 *}$, Toshimi Kaido ${ }^{2}$, Yasuhiro Ogura ${ }^{2}$, Kohei Ogawa ${ }^{2}$, Atsushi Yoshizawa ${ }^{2}$, Koichiro Hata ${ }^{2}$, \\ Yasuhiro Fujimoto ${ }^{2}$, Aya Miyagawa-Hayashino ${ }^{3}$, Hironori Haga ${ }^{3}$, Hiroyuki Marusawa ${ }^{1}$, \\ Satoshi Teramukai ${ }^{4}$, Shinji Uemoto ${ }^{2}$, Tsutomu Chiba ${ }^{1}$
}

1 Department of Gastroenterology and Hepatology, Graduate School of Medicine, Kyoto University, Kyoto, Japan, 2 Department of Surgery, Graduate School of Medicine, Kyoto University, Kyoto, Japan, 3 Department of Diagnostic Pathology, Kyoto University Hospital, Kyoto, Japan, 4 Division of Clinical Trial Design and Management, Translational Research Center, Kyoto University Hospital, Kyoto, Japan

\begin{abstract}
Background: Given the limited efficacy and high adverse event rate associated with treatment of recurrent hepatitis $C$ after liver transplantation, an individualized treatment strategy should be considered. The aim of this study was to identify predictors of response to antiviral therapy for hepatitis $C$ after living donor liver transplantation (LDLT) and to study the associated adverse events.

Methods: A retrospective chart review was performed on 125 hepatitis C virus (HCV)-positive LDLT recipients who received interferon plus ribavirin and/or peginterferon plus ribavirin therapy at Kyoto University between January 2001 and June 2011.

Results: Serum HCV RNA reached undetectable levels within 48 weeks in 77 (62\%) of 125 patients, and these patients were defined as showing virological response (VR). Of 117 patients, $50(43 \%)$ achieved sustained VR (SVR). Predictive factors associated with both VR and SVR by univariate analysis included low pretransplant serum HCV RNA levels, a non-1 HCV genotype, and low pretreatment serum HCV RNA levels. In addition, LDLT from ABO-mismatched donors was significantly associated with VR, and white cell and neutrophil counts before interferon therapy were associated with SVR. Multivariate analysis showed that 2 variables-pretransplant serum HCV RNA level less than $500 \mathrm{klU} / \mathrm{mL}$ and a non- 1 HCV genotyperemained in models of both VR and SVR and that an ABO mismatch was associated with VR. No variables with a significant effect on treatment withdrawal were found.

Conclusions: Virological response to antiviral therapy in patients with hepatitis $C$ recurring after LDLT can be predicted prior to transplant, based on pretransplant serum HCV-RNA levels and HCV genotype. LDLT from ABO-mismatched donors may contribute to more efficacious interferon therapy.
\end{abstract}

Trial Registration: UMIN-CTR UMIN000003286.

Citation: Ueda Y, Kaido T, Ogura Y, Ogawa K, Yoshizawa A, et al. (2013) Pretransplant Serum Hepatitis C Virus RNA Levels Predict Response to Antiviral Treatment after Living Donor Liver Transplantation. PLoS ONE 8(3): e58380. doi:10.1371/journal.pone.0058380

Editor: Hak Hotta, Kobe University, Japan

Received August 30, 2012; Accepted February 4, 2013; Published March 7, 2013

Copyright: (c) 2013 Ueda et al. This is an open-access article distributed under the terms of the Creative Commons Attribution License, which permits unrestricted use, distribution, and reproduction in any medium, provided the original author and source are credited.

Funding: This work was supported by Japan Society for the Promotion of Science (JSPS) Grants-in-aid for Scientific Research 21229009 and 23590972 , and Health and Labour Sciences Research Grants for Research on Intractable Diseases, and Research on Hepatitis from the Ministry of Health, Labour and Welfare, Japan. The funders had no role in study design, data collection and analysis, decision to publish, or preparation of the manuscript.

Competing Interests: The authors have declared that no competing interests exist.

*E-mail: yueda@kuhp.kyoto-u.ac.jp

\section{Introduction}

Hepatitis $\mathrm{G}$ virus (HCV) infection, leading to liver cirrhosis and hepatocellular carcinoma, is the leading indications for liver transplantation in Japan, the United States, and Western Europe. However, almost all patients who undergo liver transplantation for HCV-related liver disease develop recurrent viral infection, and $70-90 \%$ of patients suffer from histologically proven recurrent hepatitis $[1,2,3,4,5,6]$. The progression of recurrent hepatitis $\mathrm{C}$ is often accelerated and, without appropriate antiviral therapy, 10$25 \%$ of patients develop cirrhosis within 5 years after transplan- tation, resulting in poorer prognoses for $\mathrm{HCV}$-positive recipients than $\mathrm{HCV}$-negative recipients [7]. To prevent the progression of hepatitis $\mathrm{C}$ after liver transplantation, interferon-based combination therapy is commonly administered $[8,9]$. However, its efficacy in liver transplant recipients is limited, with the mean sustained virological response (SVR) rate among patients with recurrent hepatitis C after liver transplantation being only 30\% (range, 8$50 \%$ ) [10]. One of the reasons for the low SVR rate is the high rate of treatment withdrawal. Several severe adverse events have been reported in transplant recipients after interferon therapy, 
including chronic rejection and de novo autoimmune hepatitis $[11,12,13]$.

To improve the efficacy of anti-HCV treatment in patients with hepatitis $\mathrm{C}$ after liver transplantation, an individualized treatment strategy based on efficacy prediction and adverse events should be attempted. In several studies, an analysis of predictors associated with SVR was conducted in patients with recurrent hepatitis C after deceased donor liver transplantation (DDLT) $[10,14,15,16,17,18,19,20]$. In these studies, variables most frequently associated with SVR were early virological response (EVR) at 3 months of therapy, HCV genotype 2, adherence to therapy, and baseline viremia $[14,15,16,17,18,19,20]$. Of these factors, EVR and adherence to therapy can only be recognized after the initiation of treatment. However, to enable decisions on treatment indications and strategy, predictors of response that are available before initiation of therapy are more valuable. Thus, an individualized treatment strategy could be based on the identification of baseline predictive factors before interferon therapy. Moreover, no study of factors predictive of response to the interferon therapy in patients with recurrent hepatitis $\mathrm{C}$ after living donor liver transplantation (LDLT) has been reported so far. Characteristics specific to LDLT, including blood-relative donors, post-transplant liver regeneration, and ABO-incompatible liver transplantation, might cause the antiviral effects of interferon therapy in these patients to differ from those who received DDLT.

The direct-acting antiviral agents telaprevir and boceprevir recently became available for clinical use. The results of clinical trials of these agents in combination with peginterferon plus ribavirin in nontransplant patients with HCV were promising $[21,22,23,24]$. SVR rates to telaprevir-based combination therapy were significantly higher than those to the peginterferon-ribavirin combination. The efficacy in the patients who had suffered a relapse after a previous treatment by peginterferon plus ribavirin was especially striking [21,24]. The SVR rate to telaprevir basedtherapy in patients who had a previous relapse was more than $80 \%$, while that in patients who had no response to previous treatment was around $30 \%$ [24]. These results suggest that patients who show a virological response (VR) to peginterferon plus ribavirin are expected to achieve SVR after telaprevir-based therapy. Therefore, identification of factors predictive of virological response to peginterferon plus ribavirin should also prove useful when making the clinical decision about telaprevir usage. In liver transplant recipients, the use of telaprevir and boceprevir poses risks because of their inhibitory action on the enzyme cytochrome $\mathrm{P} 4503 \mathrm{~A}$, responsible for the metabolism of both tacrolimus and cyclosporine. In fact, the phase I study of telaprevir in healthy individuals revealed that it significantly increased the blood concentrations of both tacrolimus and cyclosporine [25]. Therefore, the selection of the patients for whom telaprevir is prescribed is especially important in liver transplant recipients.

Recently, a polymorphism in the interleukin-28B (IL28B) gene region, encoding interferon-lambda 3, was identified as a strong predictive factor for response to antiviral treatment in nontransplant patients with hepatitis $\mathrm{C}[26,27,28]$. In post-transplant patients, the IL28B polymorphism in both recipients and donors was shown to be associated with response to antiviral treatment [29,30]. In addition, HCV-RNA mutations, including those affecting amino acid (aa) residues 70 and 91 in the core region of $\mathrm{HCV}$ and those in the interferon sensitivity determining region (ISDR) in nonstructural protein 5A (NS5A), were also demonstrated to be predictors of response to interferon therapy in transplant recipients, as well as in nontransplant settings $[31,32,33]$. These factors could be used to predict response to antiviral therapy, but these are presently not part of a routine clinical examination and require special techniques not covered by health insurance. Moreover, probing individual genetic information poses potential ethical issues.

The aims of this study were, therefore, to identify noninvasively obtained regular baseline factors associated with VR, SVR, and treatment withdrawal, in order to elucidate the factors associated purely with response to interferon therapy, to identify the valuables related to final outcomes, and to clarify the factors associated with adverse events.

\section{Methods}

A retrospective chart review was performed for all HCVpositive liver transplant patients who received antiviral therapy with standard interferon and/or pegylated interferon in combination with ribavirin after liver transplantation at Kyoto University between January 2001 and June 2011.

\section{Patients}

Between March 1999 and June 2011, 214 HCV-positive recipients underwent LDLT at Kyoto University. Of these, 157 patients were followed up for more than 6 months after LDLT in our hospital. Anti-viral therapy was administered to 125 of the 157 patients with recurrent hepatitis C between January 2001 and June 2011. The remaining 32 patients did not receive anti-viral therapy for various reasons: serum HCV-RNA negative after $\operatorname{LDLT}(\mathrm{n}=4)$, no histological hepatitis $\mathrm{G}$ recurrence in the followup period $(\mathrm{n}=13)$, no fibrosis seen by liver histology $(\mathrm{n}=8)$, and ongoing treatment for the other complications $(n=7)$. HCV RNA concentrations and histological evidence were used to diagnose patients with recurrent hepatitis $\mathrm{C}$ after LDLT. These patients were given combination therapies with interferon plus ribavirin and/or peginterferon plus ribavirin at Kyoto University between January 2001 and June 2011. The study protocol was approved by the Ethics Committee at Kyoto University and performed in compliance with the Helsinki Declaration. Written informed consent for participation in this study was not obtained, because this study is an observational study without use of human specimen. Our institutional review board waived the need for written informed consent from the participants of the initial study.

\section{Treatment Protocol and Definition of Responses to Treatment}

Between January 2001 and April 2004, patients with recurrent hepatitis $\mathrm{C}$ after LDLT received treatment with interferon- $\alpha-2 b$ (3 or 6 mega units, 3 times/week) plus ribavirin (400-800 $\mathrm{mg} /$ day orally), for the first 6 months. This was followed by interferon monotherapy for 6 months [34]. Forty patients received this treatment. Of the 40 patients, 14 patients achieved SVR and 9 withdrew from the treatment protocol. The remaining 17 patients, including 2 who relapsed and 15 nonresponders were retreated by the following protocol with peginterferon and rebavirin. Between May 2004 and June 2011, patients received combination therapy with peginterferon- $\alpha-2 \mathrm{~b}(1.5 \mu \mathrm{g} / \mathrm{kg})$ plus ribavirin $(400-800 \mathrm{mg} /$ day orally) [35]. Patients who acquired a negative serum HCV RNA status within 12 months after treatment initiation continued to receive the treatment for an additional 12 months before treatment termination. Total 102 patients, including 17 patients who had previously treated with standard interferon plus ribavirin and did not achieve SVR, were treated with this treatment protocol. Patients who were negative for serum HCV RNA for more than 6 months after completion of interferon therapy were defined as having achieved SVR. If serum HCV RNA was positive after 12 months of treatment, therapy was discontinued or 
switched to maintenance therapy with low-dose peginterferon [36], and the patient was classified as having shown no response. Treatment was discontinued in patients with severe adverse events. Additionally, peginterferon treatment was discontinued when neutrophil and platelet counts fell below $500 / \mu \mathrm{L}$ and $30000 / \mu \mathrm{L}$, respectively, and ribavirin was discontinued when hemoglobin levels fell below $8 \mathrm{~g} / \mathrm{dL}$.

We studied the final outcomes of the treatment with peginterferon plus ribavirin $(\mathrm{n}=102)$ and with standard interferon plus ribavirin $(\mathrm{n}=23)$.

\section{Histological Assessment}

Liver biopsies were performed when patients' alanine aminotransferase (ALT) levels were more than twice the normal upper limit, or at yearly intervals, with informed consent. Biopsy specimens were evaluated by 2 pathologists (H.H. and A.M-H.) with extensive experience in the pathology of liver transplantation. Necroinflammatory activity (A0-A3) and fibrosis stage (F0-F4) were assessed using METAVIR scores [37,38]. Activity was graded as A0 (no activity), A1 (mild activity), A2 (moderate activity), or A3 (severe activity); Fibrosis was staged as F0 (no fibrosis), F1 (mild fibrosis), F2 (moderate fibrosis), F3 (severe fibrosis), or F4 (cirrhosis).

\section{Immunosuppression}

Tacrolimus and low-dose steroid therapy were administered to induce immunosuppression in most patients [34]. Four patients received cyclosporine microemulsions instead of tacrolimus. Mycophenolate mofetil was administered to patients who experienced refractory rejection or required reduction of tacrolimus or cyclosporine doses due to adverse events. Patients who received $\mathrm{ABO}$ blood-type incompatible transplants were treated with rituximab, plasma exchange, and hepatic artery or portal vein infusion with prostaglandin E1 and methylprednisolone [39].

\section{Virological Assays}

HCV genotype was determined using a genotyping system based on polymerase chain reaction (PCR) to amplify the core region using genotype-specific PCR primers [40]. Serum HCV RNA load was evaluated before LDLT, before interferon treatment, once a month during treatment, and 24 weeks after treatment, using PCR and an Amplicor HCV assay (Cobas Amplicor HCV Monitor, Roche Molecular Systems, Pleasanton, CA, USA) until April 2008, or a real-time PCR-based quantitation method for HCV (COBAS AmpliPrep/COBAS TaqMan HCV Test, Roche Molecular Systems, Pleasanton, CA, USA) from May 2008. Detection of amino acid substitutions in the HCV core region was performed using the method reported previously [31].

\section{Statistical Analysis}

To evaluate the association between the patient characteristics and the outcomes (VR, SVR, or withdrawal), the Wald test was performed based on a logistic regression model. Multivariate logistic regression analysis with backward variable selection was used to identify independent and significant predictors for the outcomes, and to estimate the odds ratio (OR) ant its 95\% confidence interval (CI). A p-value of 0.05 was used for variable selection and was regarded as significant. Statistical analyses were performed using SAS version 9.2 (SAS Institute Inc., Cary NC).

\section{Results}

\section{Patient Characteristics}

This study included $125 \mathrm{HCV}$-infected liver transplant patients treated with standard interferon and/or pegylated interferon in combination with ribavirin for recurrent hepatitis $\mathrm{C}$ after LDLT. Of the 125 patients, 69 (55\%) were male, and the median age was 57 years (range: 15-70) at the beginning of the therapy. Most patients were infected with HCV genotype $1 \mathrm{~b}(\mathrm{n}=103,82 \%)$. HCV genotypes of the remaining patients were $2 \mathrm{a}(\mathrm{n}=13), 2 \mathrm{~b}$ $(\mathrm{n}=5)$, 3a plus $3 \mathrm{~b}(\mathrm{n}=1)$, not determined $(\mathrm{n}=2)$, and not examined $(\mathrm{n}=1)$. Median serum HCV RNA load was $410 \mathrm{kIU} /$ $\mathrm{mL}$ (range: $<0.5-5000<\mathrm{kIU} / \mathrm{mL}$ ) before LDLT, and $3260 \mathrm{kIU} /$ $\mathrm{mL}$ (range: $31-69000<\mathrm{kIU} / \mathrm{mL}$ ) at the beginning of the interferon therapy after LDLT. The median donor age was 41 (range: 19-65) years. Seventy-two donors (58\%) were male, and 86 (69\%) were related to the recipients. The graft type was the right lobe in 109 patients $(87 \%)$, and the left lobe in 16 patients $(13 \%)$. The blood type combination was incompatible in 26 patients $(21 \%)$. The median time to treatment initiation after LDLT was 9.0 months (1.1-85.3 months). Before treatment, the necroinflammatory activity was Al or greater in all patients, and 104 patients (83\%) had a fibrosis score of F1 or greater (METAVIR score). Tacrolimus-based immunosuppression was used in 116 patients (93\%). Among patients receiving tacrolimus for immunosuppression, the mean serum trough level was $6.0 \mathrm{ng} / \mathrm{mL}$ (range: $2.0-$ 12.7) at the initiation of interferon therapy. In addition to calcineurin inhibitors, mycophenolate mofetil and prednisolone were used at the initiation of the interferon treatment in $36(29 \%)$ and $19(15 \%)$ patients, respectively.

\section{Efficacy of Interferon Therapy}

Of the 125 patients who received interferon therapy, serum HCV RNA reached undetectable levels (less than $0.05 \mathrm{kIU} / \mathrm{mL}$ ) within 48 weeks in 77 patients (62\%) (Figure 1). These patients were defined as showing virological response (VR). Of the remaining 48 patients, 2 patients received treatment for less than 48 weeks, and 15 patients withdrew from the treatment protocol within 48 weeks because of worsening of liver function $(n=5)$, recurrent hepatocellular carcinoma $(n=2)$, ascites $(n=2)$, anemia $(\mathrm{n}=1)$, leucopenia $(\mathrm{n}=1)$, brain hemorrhage $(\mathrm{n}=1)$, biliary complication $(n=1)$, sepsis $(n=1)$, or myocardial infarction $(n=1)$. The remaining 31 patients with detectable HCV RNA in the serum 48 weeks after the initiation of the treatment were placed in the non-VR group. All patients in the non-VR group received peginterferon plus ribavirin therapy, including 9 patients who had previously treated with standard interferon plus ribavirin and did not achieve SVR. Of the patients with VR, 11 discontinued the treatment protocol within 24 weeks after serum HCV-RNA became negative, and 6 patients are still under treatment. The reasons for discontinuation were biliary complications $(n=2)$, worsening of liver function $(n=2)$, general fatigue $(\mathrm{n}=2)$, recurrent hepatocellular carcinoma $(\mathrm{n}=1)$, leucopenia $(n=1)$, hemoptysis $(n=1)$, brain tumor $(n=1)$, and depression $(\mathrm{n}=1)$. Of 60 patients who achieved VR and completed the treatment protocol, 50 achieved SVR and 10 relapsed. None of the non-VR patients achieved VR even after more than 48 weeks of treatment, and were classified as nonresponder (NR).

In summary, among the 117 patients in whom the final outcomes of the treatment could be evaluated, 50 patients $(43 \%)$ achieved SVR, and the remaining 67 patients, including 10 who relapsed (9\%), $31 \mathrm{NR}(26 \%)$, and 26 withdrawals $(22 \%)$, were classified as non-SVR. 


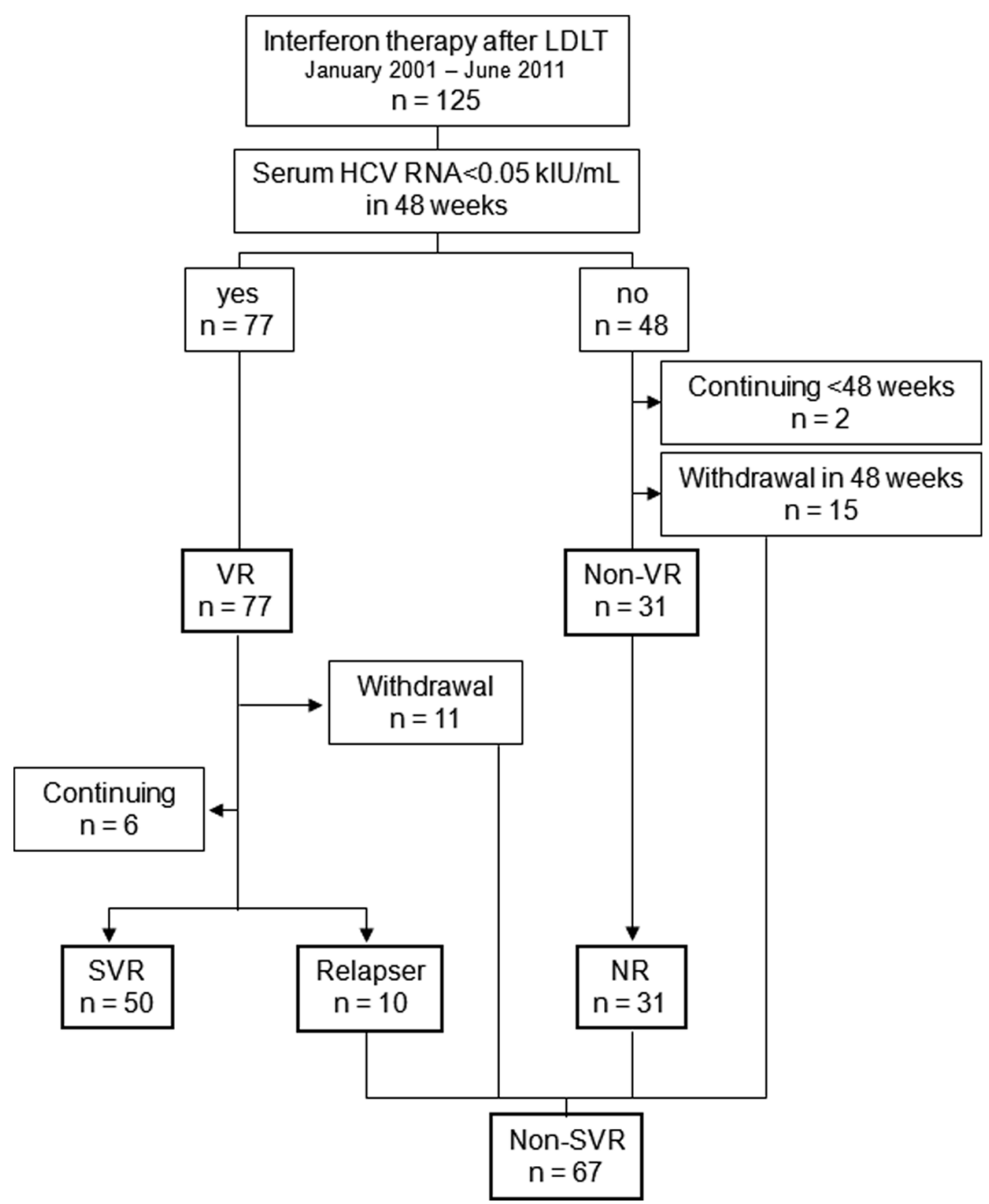

Figure 1. Flow diagram showing the outcome of interferon therapy in patients with recurrent hepatitis $\mathrm{C}$ after living donor liver transplantation (LDLT) and indicating the classification of patients in this study. N, number of patients; VR, virological response; SVR, sustained virological response; NR, nonresponder.

doi:10.1371/journal.pone.0058380.g001

\section{Factors Predictive of Virological Response}

Factors that could predict virological response were analyzed by comparing patients in the VR $(\mathrm{n}=77)$ and non-VR $(\mathrm{n}=31)$ groups (Table 1). Univariate analysis demonstrated that a low pretransplant serum HCV RNA level (less than $500 \mathrm{kIU} / \mathrm{mL}, P<0.001$; and less than $1000 \mathrm{kIU} / \mathrm{mL}, P<0.001)$, an ABO-mismatched donor $(P=0.036)$, HCV genotype (non-1, $P=0.001$ ), and a low pretreatment serum HCV RNA level (less than $5000 \mathrm{kIU} / \mathrm{mL}$, $P=0.020)$ were significantly associated with VR. There were no significant associations with any other variables, including donor factors. Multivariate analysis revealed that the 3 variables that retained a significant association in the model were a pretransplant serum HCV RNA level less than $500 \mathrm{kIU} / \mathrm{mL}$ [odds ratio (OR): $0.178,95 \%$ confidence interval (CI): $0.054-0.535, P=0.001]$, a non-1 HCV genotype (OR: 0.087, 95\% CI: 0.000-0.589, $P=0.008$ ), and an ABO-mismatched donor (OR: 5.492, 95\% CI: $1.004-58.06, P=0.049$ ) (Table 2). All 20 patients with a non-1
HCV genotype achieved VR, while VR rate in patients with the HCV genotype 1 was $65 \%$ (57 out of 88 patients). In the patients with HCV genotype 1, VR rate was $80 \%$ (36 of 45 patients) when pretransplant serum HCV-RNA level was less than $500 \mathrm{kIU} / \mathrm{mL}$ and $42 \%$ (15 of 36 patients) when it was $500 \mathrm{kIU} / \mathrm{mL}$ or more. Among 22 recipients from ABO-mismatched donors, 20 patients $(91 \%)$ showed VR, while $57(66 \%)$ out of 86 patients who underwent LDLT from an ABO-matched (identical and compatible) donor achieved VR.

\section{Factors Predictive of SVR}

The same variables were analyzed to clarify factors that predicted SVR by comparing patients in the SVR $(n=50)$ and non-SVR $(n=67)$ groups (Table 1$)$. By univariate analysis, the same variables that had a significant association with VR were identified as significant predictive factors for SVR-low pretransplant serum HCV RNA levels (less than $100 \mathrm{kIU} / \mathrm{mL}, P=0.028$; 
Table 1. Baseline predictive factors before liver transplantation (pre-LT), at liver transplantation (at LT), and before interferon therapy (pre-IFN) associated with virorogical response (VR) and sustained VR (SVR): Univariate analysis.

\begin{tabular}{|c|c|c|c|c|c|c|c|}
\hline & & \multirow{2}{*}{$\begin{array}{l}\text { VR } \\
n=77\end{array}$} & \multirow{2}{*}{$\begin{array}{l}\text { non-VR } \\
n=31\end{array}$} & \multirow[t]{2}{*}{$P$} & \multirow{2}{*}{$\begin{array}{l}\text { SVR } \\
n=50\end{array}$} & \multirow{2}{*}{$\begin{array}{l}\text { non-SVR } \\
n=67\end{array}$} & \multirow{2}{*}{$P$} \\
\hline & & & & & & & \\
\hline Age at LT (years) & & $55(8-67)$ & $56(37-69)$ & 0.462 & $54.5(8-67)$ & $56(30-69)$ & 0.212 \\
\hline \multirow[t]{2}{*}{ Gender } & Male & $45(74 \%)$ & $16(26 \%)$ & 0.518 & $30(46 \%)$ & 35 (54\%) & 0.404 \\
\hline & Female & $32(68 \%)$ & $15(32 \%)$ & & $20(38 \%)$ & 32 (62\%) & \\
\hline \multirow[t]{2}{*}{ HCC pre-LT } & No & $29(71 \%)$ & $12(29 \%)$ & 0.919 & $18(43 \%)$ & $24(57 \%)$ & 0.984 \\
\hline & Yes & 48 (72\%) & $19(28 \%)$ & & 32 (43\%) & $43(57 \%)$ & \\
\hline MELD pre-LT & & $15.5(3-51)$ & $15(6-25)$ & 0.403 & $16(3-51)$ & $15(0-43)$ & 0.616 \\
\hline \multirow[t]{3}{*}{ Child-Pugh pre-LT } & $A / B$ & 35 (74\%) & $12(26 \%)$ & 0.488 & $25(49 \%)$ & $26(51 \%)$ & 0.192 \\
\hline & $\mathrm{C}$ & $41(68 \%)$ & 19 (32\%) & & $24(37 \%)$ & $41(63 \%)$ & \\
\hline & unknown & 1 & 0 & & 1 & 0 & \\
\hline \multirow[t]{3}{*}{ Serum HCV RNA pre-LT } & $<100 \mathrm{kIU} / \mathrm{mL}$ & $16(89 \%)$ & $2(11 \%)$ & 0.063 & 11 (65\%) & $6(35 \%)$ & 0.028 \\
\hline & $100 \mathrm{kIU} / \mathrm{mL} \leq$ & $52(65 \%)$ & $28(35 \%)$ & & 31 (35\%) & 57 (65\%) & \\
\hline & unknown & 9 & 1 & & 8 & 4 & \\
\hline \multirow[t]{3}{*}{ Serum HCV RNA pre-LT } & $<500 \mathrm{kIU} / \mathrm{mL}$ & $50(85 \%)$ & $9(15 \%)$ & $<0.001$ & $30(55 \%)$ & $25(45 \%)$ & 0.002 \\
\hline & $500 \mathrm{kIU} / \mathrm{mL} \leq$ & $18(46 \%)$ & $21(54 \%)$ & & $12(24 \%)$ & $38(76 \%)$ & \\
\hline & unknown & 9 & 1 & & 8 & 4 & \\
\hline \multirow[t]{3}{*}{ Serum HCV RNA pre-LT } & $<1000 \mathrm{kIU} / \mathrm{mL}$ & $56(81 \%)$ & $13(19 \%)$ & $<0.001$ & 34 (49\%) & $36(51 \%)$ & 0.013 \\
\hline & $1000 \mathrm{kIU} / \mathrm{mL} \leq$ & 12 (41\%) & 17 (59\%) & & $8(23 \%)$ & 27 (77\%) & \\
\hline & unknown & 9 & 1 & & 8 & 4 & \\
\hline \multirow[t]{3}{*}{ HCV genotype } & Non-1 & $20(100 \%)$ & $0(0 \%)$ & 0.001 & $15(79 \%)$ & $4(21 \%)$ & 0.002 \\
\hline & 1 & 57 (65\%) & $31(35 \%)$ & & 35 (36\%) & $62(64 \%)$ & \\
\hline & unknown & & & & 0 & 1 & \\
\hline Donor age at LT (years) & & $42(20-63)$ & $38(21-61)$ & 0.504 & $43(20-60)$ & $38(19-63)$ & 0.748 \\
\hline \multirow[t]{2}{*}{ Donor gender at LT } & Male & $41(67 \%)$ & $20(33 \%)$ & 0.287 & $27(40 \%)$ & $40(60 \%)$ & 0.538 \\
\hline & Female & $36(77 \%)$ & $11(23 \%)$ & & $23(46 \%)$ & 27 (54\%) & \\
\hline \multirow[t]{2}{*}{ Sex mismatch } & Match & $28(72 \%)$ & $11(28 \%)$ & 0.932 & $18(43 \%)$ & $24(57 \%)$ & 0.984 \\
\hline & Mismatch & 49 (71\%) & $20(29 \%)$ & & $32(43 \%)$ & $43(57 \%)$ & \\
\hline \multirow[t]{2}{*}{ ABO mismatch } & Match & $57(66 \%)$ & 29 (34\%) & 0.036 & $38(40 \%)$ & $56(60 \%)$ & 0.310 \\
\hline & Mismatch & $20(91 \%)$ & $2(9 \%)$ & & $12(52 \%)$ & $11(48 \%)$ & \\
\hline \multirow[t]{2}{*}{ Relation of donor } & Nonrelated & $24(73 \%)$ & $9(27 \%)$ & 0.827 & $16(44 \%)$ & $20(56 \%)$ & 0.803 \\
\hline & Related & $53(71 \%)$ & $22(29 \%)$ & & $34(42 \%)$ & $47(58 \%)$ & \\
\hline \multirow[t]{2}{*}{ Graft type } & Left lobe & $13(81 \%)$ & $3(19 \%)$ & 0.347 & $8(62 \%)$ & $5(38 \%)$ & 0.155 \\
\hline & Right lobe & $64(70 \%)$ & $28(30 \%)$ & & $42(40 \%)$ & $62(60 \%)$ & \\
\hline \multirow[t]{2}{*}{ Splenectomy } & No & $38(68 \%)$ & $18(32 \%)$ & 0.413 & $25(39 \%)$ & 39 (61\%) & 0.378 \\
\hline & Yes & 39 (75\%) & $13(25 \%)$ & & $25(47 \%)$ & $28(53 \%)$ & \\
\hline Age pre-IFN (years) & & $57(15-68)$ & $57(41-70)$ & 0.494 & $56(15-68)$ & $57(32-70)$ & 0.200 \\
\hline Months from LT to therapy & & $9.2(1.1-85.3)$ & $8.9(1.8-59.0)$ & 0.846 & $9.0(1.3-85.3)$ & $9.0(1.3-72.4)$ & 0.879 \\
\hline $\begin{array}{l}\text { Trough level for tacrolimus (ng/mL) } \\
\text { pre-IFN }\end{array}$ & & $5.9(2.0-10.9)$ & $6.4(3.3-10.6)$ & 0.323 & $6.2(2.2-9.5)$ & $5.9(2.0-12.7)$ & 0.933 \\
\hline \multirow[t]{2}{*}{ MMF pre-IFN } & No & $55(71 \%)$ & $23(29 \%)$ & 0.772 & $36(43 \%)$ & $48(57 \%)$ & 0.966 \\
\hline & Yes & $22(73 \%)$ & $8(27 \%)$ & & $14(42 \%)$ & 19 (58\%) & \\
\hline \multirow[t]{2}{*}{ Prednisolone pre-IFN } & No & $64(70 \%)$ & $28(30 \%)$ & 0.347 & $41(41 \%)$ & 60 (59\%) & 0.245 \\
\hline & Yes & $13(81 \%)$ & $3(19 \%)$ & & $9(56 \%)$ & 7 (44\%) & \\
\hline Serum HCV RNA pre-IFN & $<1000 \mathrm{kIU} / \mathrm{mL}$ & 17 (89\%) & $2(11 \%)$ & 0.064 & $8(38 \%)$ & $13(62 \%)$ & 0.583 \\
\hline & $1000 \mathrm{kIU} / \mathrm{mL} \leq$ & $58(67 \%)$ & $29(33 \%)$ & & $42(45 \%)$ & $52(55 \%)$ & \\
\hline & unknown & 2 & 0 & & 0 & 2 & \\
\hline Serum HCV RNA pre-IFN & $<5000 \mathrm{kIU} / \mathrm{mL}$ & $52(78 \%)$ & $15(22 \%)$ & 0.020 & $36(50 \%)$ & $36(50 \%)$ & 0.030 \\
\hline & $5000 \mathrm{kIU} / \mathrm{mL} \leq$ & 18 (55\%) & $15(45 \%)$ & & $10(28 \%)$ & $26(72 \%)$ & \\
\hline & unknown & 7 & 1 & & 4 & 5 & \\
\hline
\end{tabular}


Table 1. Cont.

\begin{tabular}{|c|c|c|c|c|c|c|c|}
\hline & & \multirow{2}{*}{$\begin{array}{l}\text { VR } \\
n=77\end{array}$} & \multirow{2}{*}{$\begin{array}{l}\text { non-VR } \\
\mathbf{n = 3 1}\end{array}$} & \multirow{2}{*}{$P$} & \multirow{2}{*}{$\begin{array}{l}\text { SVR } \\
n=50\end{array}$} & \multirow{2}{*}{$\begin{array}{l}\text { non-SVR } \\
n=67\end{array}$} & \multirow{2}{*}{$P$} \\
\hline & & & & & & & \\
\hline \multicolumn{2}{|l|}{ White cell count $(102 / \mathrm{mL})$} & $51(13-114)$ & $49(17-98)$ & 0.135 & $49(18-114)$ & $48.5(13-99)$ & 0.049 \\
\hline \multicolumn{2}{|l|}{ Neutrophil count $(102 / \mathrm{mL})$} & $26(8-89)$ & $22(11-58)$ & 0.127 & $26(11-89)$ & $23(8-61)$ & 0.044 \\
\hline \multicolumn{2}{|l|}{ Hemoglobin (g/dL) } & $12.0(9.2-17.2)$ & $12.0(8.9-17.9)$ & 0.638 & $12.0(9.4-17.2)$ & $11.8(8.9-17.9)$ & 0.157 \\
\hline \multicolumn{2}{|l|}{ Platelet count $(104 / \mathrm{mL})$} & $21.7(4.7-58.1)$ & $15.1(4.3-40.0)$ & 0.153 & $20.3(5.0-58.1)$ & $15.8(4.3-45.8)$ & 0.165 \\
\hline \multicolumn{2}{|l|}{ AST (IU/L) } & $78(19-352)$ & $72(25-464)$ & 0.677 & $85(21-352)$ & $75(24-547)$ & 0.887 \\
\hline \multicolumn{2}{|l|}{ ALT (IU/L) } & $93(18-395)$ & $82(21-392)$ & 0.544 & $106(22-395)$ & $82(18-597)$ & 0.251 \\
\hline \multicolumn{2}{|l|}{ ALP (IU/L) } & $461(199-1985)$ & $433(168-2977)$ & 0.345 & $470(204-1985)$ & $470(168-2977)$ & 0.610 \\
\hline \multicolumn{2}{|l|}{ g-GTP (IU/L) } & $118.5(15-1623)$ & $114(20-1827)$ & 0.856 & $141(15-1623)$ & $115(20-1827)$ & 0.356 \\
\hline \multicolumn{2}{|l|}{ Bilirubin (mg/dL) } & $0.9(0.3-11.0)$ & $0.9(0.3-10.4)$ & 0.827 & $0.9(0.4-11.0)$ & $1.0(0.3-13.7)$ & 0.611 \\
\hline \multirow[t]{3}{*}{ Activity grade pre-IFN } & A1 & $54(75 \%)$ & $18(25 \%)$ & 0.448 & $35(47 \%)$ & $40(53 \%)$ & 0.517 \\
\hline & A2 & $22(65 \%)$ & $12(35 \%)$ & & $14(36 \%)$ & $25(64 \%)$ & \\
\hline & A3 & $1(50 \%)$ & $1(50 \%)$ & & $1(33 \%)$ & $2(67 \%)$ & \\
\hline \multirow[t]{3}{*}{ Fibrosis stage pre-IFN } & F0 & $9(60 \%)$ & $6(40 \%)$ & 0.446 & $6(32 \%)$ & $13(68 \%)$ & 0.530 \\
\hline & F1 & $54(75 \%)$ & $18(25 \%)$ & & $34(46 \%)$ & $40(54 \%)$ & \\
\hline & $F 2 / 3$ & $14(67 \%)$ & $7(33 \%)$ & & $10(42 \%)$ & $14(58 \%)$ & \\
\hline \multirow[t]{3}{*}{ Steatosis $(5 \%<)$ pre-IFN } & No & $40(69 \%)$ & $18(31 \%)$ & 0.609 & $27(42 \%)$ & $38(58 \%)$ & 0.633 \\
\hline & Yes & $36(73 \%)$ & $13(27 \%)$ & & $23(46 \%)$ & 27 (54\%) & \\
\hline & unknown & 1 & 0 & & 0 & 2 & \\
\hline \multirow[t]{3}{*}{ Cholestasis pre-IFN } & No & 58 (71\%) & $24(29 \%)$ & 0.903 & $38(42 \%)$ & $53(58 \%)$ & 0.577 \\
\hline & Yes & 18 (72\%) & 7 (28\%) & & $12(48 \%)$ & $13(52 \%)$ & \\
\hline & unknown & 1 & 0 & & 0 & 1 & \\
\hline
\end{tabular}

NOTE. Qualitative variables are shown in number; and quantitative variables expressed as median (range). P-values are calculated by Wald test for logistic regression analysis.

LT, liver transplantation; HCC, hepatocellular carcinoma; MELD, model for end-stage liver disease; HCV, hepatitis C virus; MMF, mycophenolate mofetil; AST, aspartate aminotransferase; ALT, alanine aminotransferase; ALP, alkaline phosphatase; g-GTP, gamma-glutamyl transpeptidase.

doi:10.1371/journal.pone.0058380.t001

less than $500 \mathrm{kIU} / \mathrm{mL}, P=0.002$; and less than $1000 \mathrm{kIU} / \mathrm{mL}$, $P=0.013$ ), HCV genotype (non- $1, P=0.002$ ), and low pretreatment serum HCV RNA levels (less than $5000 \mathrm{kIU} / \mathrm{mL}$, $P=0.030)$. In addition, white cell count $(P=0.049)$ and neutrophil count $(P=0.044)$ before interferon therapy were significantly associated with SVR. Multivariate analysis showed that 2 variables were independently associated with SVR-a non-1 HCV genotype (OR: 0.182, 95\% CI: 0.054-0.614, $P=0.006$ ), and pretransplant serum HCV RNA levels lower than $500 \mathrm{kIU} / \mathrm{mL}$ (OR: 0.310 , 95\% CI: $0.130-0.742, P=0.009$ ) (Table 3). SVR rate among patients with a non-1 HCV genotype was 79\% (15 of 19 patients) on average, $83 \%$ (10 of 12 patients) when pretransplant serum
HCV-RNA level was less than $500 \mathrm{kIU} / \mathrm{mL}$, and $50 \%$ (2 of 4 patients) when it was $500 \mathrm{kIU} / \mathrm{mL}$ or more. In patients with $\mathrm{HCV}$ genotype 1 , SVR rate was $36 \%$ (35 of 97 patients) on average, $47 \%$ (20 of 43 patients) when pretransplant serum HCV-RNA level was less than $500 \mathrm{kIU} / \mathrm{mL}$, and $22 \%$ (10 of 45 patients) when it was $500 \mathrm{kIU} / \mathrm{mL}$ or more.

\section{Amino Acid Substitutions in Core Region of HCV}

To determine the viral factors that predicted VR and SVR in patients infected with $\mathrm{HCV}$ genotype $1 \mathrm{~b}$, association of aa substitutions at aa 70 of arginine or glutamine/histidine and aa

Table 2. Predictive factors associated with virological response (VR): Multivariate analysis.

\begin{tabular}{|c|c|c|c|c|}
\hline & & Odds Ratio & $\mathbf{9 5 \%}$ confidence intervals & P-value \\
\hline \multirow[t]{2}{*}{ Serum HCV RNA pre-LT } & $<500 \mathrm{klU} / \mathrm{mL}$ & 1 & - & - \\
\hline & $500 \mathrm{klU} / \mathrm{mL} \leq$ & 0.178 & $0.054-0.535$ & 0.001 \\
\hline \multirow[t]{2}{*}{ HCV genotype } & Non-1 & 1 & - & - \\
\hline & 1 & 0.087 & $0.000-0.589$ & 0.008 \\
\hline \multirow[t]{2}{*}{$\mathrm{ABO}$ mismatch } & Match & 1 & - & - \\
\hline & Mismatch & 5.492 & $1.004-58.06$ & 0.049 \\
\hline
\end{tabular}

HCV, hepatitis C virus; LT, liver transplantation.

doi:10.1371/journal.pone.0058380.t002 
Table 3. Predictive factors associated with sustained virological response (SVR): Multivariate analysis.

\begin{tabular}{lllll}
\hline & & & & \\
\hline & & Odds Ratio & 95\% confidence intervals & P-value \\
\hline HCV genotype & Non-1 & 1 & - & - \\
Serum HCV RNA pre-LT & 1 & 0.182 & $0.054-0.614$ & 0.006 \\
& $<500 \mathrm{kIU} / \mathrm{mL}$ & 1 & - & - \\
\hline
\end{tabular}

HCV, hepatitis C virus; LT, liver transplantation.

doi:10.1371/journal.pone.0058380.t003

91 of leucine or methionine with VR and SVR were analyzed in 40 patients, whose pre-treatment sera were stored (Table 4). As a result, substitutions of both aa 70 and aa 91 were not significantly associated with VR and SVR.

\section{Predictors of Withdrawal from Therapy}

Predictive factors for withdrawal from the treatment protocol were evaluated by comparing 26 patients who withdrew from the treatment protocol and the patients who completed the treatment including patients with SVR, patients who relapsed, and NR. None of the variables analyzed had a significant effect on withdrawal (Data not shown).

\section{Discussion}

In this study, we identified 2 independent predictors of SVR in patients with recurrent hepatitis $\mathrm{C}$ after LDLT by multivariate analysis: A non-1 HCV genotype and pretransplant serum HCVRNA levels lower than $500 \mathrm{kIU} / \mathrm{mL}$. The same factors were identified as predictors for VR, which purely indicates response to interferon therapy, by excluding the influences of the premature termination of the therapy and virological relapse after termination of the treatment. In addition, an ABO-incompatible LDLT was identified as an independent variable predicting VR.

In non-transplant settings, pretreatment predictors of response to interferon therapy have been analyzed in many studies, and the viral genotype and pretreatment viral load have been almost invariably shown to be 2 major predictors of SVR $[41,42,43,44]$. SVR rates were higher in patients infected with a non-1 HCV genotype and in those with a low pretreatment viral load. These 2 factors have been also identified in several reports $[16,17,18,19]$ as factors predicting SVR in patients with recurrent hepatitis $\mathrm{C}$ after DDLT. In the present study, a non-1 HCV genotype was again identified as an independent predictive factor for both VR and SVR in patients with recurrent hepatitis $\mathrm{G}$ after LDLT by multivariate analysis. A pretreatment viral load $<5000 \mathrm{kIU} / \mathrm{mL}$ was also a significant predictive factor by univariate analysis, but it was not an independently associated variable by multivariate analysis. On the other hand, pretransplant viral load was identified as an independent variable predictive of both VR and SVR by multivariate analysis.

While reports of factors that can control viral load exist, the mechanism by which serum HCV-RNA levels are regulated has not yet been completely clarified. A correlation between mutations in the ISDR sequence in the NS5A region of the HCV genome and serum HCV RNA levels has been reported. We did not analyze this viral factor in the current study; however, it is possible that the HCV genome sequence determines both pretransplant viremia and response to interferon therapy. The host polymorphism in IL28B, which was identified as a strong predictor of virological response to interferon therapy in patients with hepatitis C, was recently reported to be associated with baseline viral load $[26,45]$. The allele associated with a better treatment response is associated with a higher baseline viral load. This finding does not correspond with our results showing that a low HCV load predicts a better response to treatment. We speculate that the balance between host immunity and HCV replication regulates the serum HCV load, and that this balance also determines VR. As pretreatment viral load in post-transplant patients is influenced by immunosuppressive agents, the original host-virus balance

Table 4. Association of amino acid substitutions in the core region with virorogical response (VR) and sustained VR (SVR) in 40 patients infected with HCV genotype $1 \mathrm{~b}$ : Univariate analysis.

\begin{tabular}{|c|c|c|c|c|c|c|c|}
\hline & & \multirow{2}{*}{$\begin{array}{l}\text { VR } \\
n=22\end{array}$} & \multirow{2}{*}{$\begin{array}{l}\text { non-VR } \\
n=13\end{array}$} & \multirow[t]{2}{*}{$P$} & \multirow{2}{*}{$\begin{array}{l}\text { SVR } \\
n=14\end{array}$} & \multirow{2}{*}{$\begin{array}{l}\text { non-SVR } \\
n=24\end{array}$} & \multirow[t]{2}{*}{$P$} \\
\hline & & & & & & & \\
\hline \multirow[t]{2}{*}{ Core aa 70} & Arg & $9(75 \%)$ & $3(25 \%)$ & 0.289 & $7(50 \%)$ & 7 (50\%) & 0.204 \\
\hline & $\mathrm{Gln} / \mathrm{His}$ & $13(57 \%)$ & $10(43 \%)$ & & $7(29 \%)$ & $17(71 \%)$ & \\
\hline \multirow[t]{2}{*}{ Core aa 91} & Leu & $14(64 \%)$ & $8(36 \%)$ & 0.902 & $9(38 \%)$ & $15(63 \%)$ & 0.912 \\
\hline & Met & $8(62 \%)$ & $5(38 \%)$ & & $5(36 \%)$ & $9(64 \%)$ & \\
\hline \multirow[t]{2}{*}{ Core aa 70 and 91} & 70 Arg and 91 Leu & $6(67 \%)$ & $3(33 \%)$ & 0.784 & $5(50 \%)$ & $5(50 \%)$ & 0.320 \\
\hline & Others & $16(62 \%)$ & $10(38 \%)$ & & $9(32 \%)$ & $19(68 \%)$ & \\
\hline \multirow[t]{2}{*}{ Core aa 70 and 91} & $70 \mathrm{Gln} / \mathrm{His}$ and $91 \mathrm{Met}$ & $5(50 \%)$ & $5(50 \%)$ & 0.324 & $3(30 \%)$ & 7 (70\%) & 0.603 \\
\hline & Others & 17 (68\%) & 8 (32\%) & & 11 (39\%) & 17 (61\%) & \\
\hline
\end{tabular}

NOTE. Data are shown in number. P-values are calculated by Wald test for logistic regression analysis.

Arg, Arginine; Gln, glutamine; His, histidine; Leu, leucine; Met, methionine.

doi:10.1371/journal.pone.0058380.t004 
would be reflected better by serum HCV levels before transplantation than by those after transplantation. It is unclear whether this result is specific to LDLT or holds true for both DDLT and LDLT. The significance of pretransplant viral load in DDLT as a predictor for virological response to post-transplant interferon therapy has not been analyzed in most previous studies [10]. Further analysis in patients who receive DDLT could help clarify the underlying mechanism.

Liver transplantation across the ABO blood-type barrier (ABOincompatible) is generally contraindicated because of the possibility of graft loss caused by antibody-mediated rejection and is performed under exceptional circumstances as a rescue option in an emergent situation. However, ABO-incompatible LDLT has been performed in Japan to overcome organ shortage problems. Recently, rituximab prophylaxis and local infusion of prostaglandin E1 and steroids were established as therapeutic measures for recipients who underwent ABO-incompatible LDLT, and these treatments improved outcomes [46]. Interestingly, in this study, we found that an ABO-mismatched donor is associated with VR to interferon therapy. The reason for this interesting finding is unclear, but it is possible that either subclinical antibody-mediated rejection or drugs such as rituximab and prostaglandin E1 used in ABO-incompatible recipients may contribute to the higher VR to interferon therapy. There is hope that future studies to clarify the basic mechanism underlying this result will lead to a novel strategy to improve the efficacy of interferon therapy in patients with hepatitis C.

Amino acid substitutions of core region of $\mathrm{HCV}$ were not associated with treatment response in our analysis. We do not know the reason for the difference of impact of substitution of core aa 70 and aa 91 on virological response to interferon therapy from a previous report, in which SVR rate were significantly higher in transplant recipients with aa 70 of arginine and aa 91 of leucine of core region of HCV [33]. As sample size of both the previous study and our present study are small, and our present study did not assess the other HCV RNA mutations, including ISDR [32] and interferon/ribavirin resistance-determining region [47] in NS5A, and IL28B polymorphism in recipients and donors, further analysis should be required in larger cohorts.

Another aim of this study was to identify predictive variables for adverse events during interferon therapy, but none of the studied

\section{References}

1. Berenguer M, Prieto M, San Juan F, Rayon JM, Martinez F, et al. (2002) Contribution of donor age to the recent decrease in patient survival among HCV-infected liver transplant recipients. Hepatology 36: 202-210.

2. Feray C, Caccamo L, Alexander GJ, Ducot B, Gugenheim J, et al. (1999) European collaborative study on factors influencing outcome after liver transplantation for hepatitis C. European Concerted Action on Viral Hepatitis (EUROHEP) Group. Gastroenterology 117: 619-625.

3. Forman LM, Lewis JD, Berlin JA, Feldman HI, Lucey MR (2002) The association between hepatitis $\mathrm{C}$ infection and survival after orthotopic liver transplantation. Gastroenterology 122: 889-896.

4. Gane E (2003) The natural history and outcome of liver transplantation in hepatitis C virus-infected recipients. Liver Transpl 9: S28-34.

5. Prieto M, Berenguer M, Rayon JM, Cordoba J, Arguello L, et al. (1999) High incidence of allograft cirrhosis in hepatitis $\mathrm{C}$ virus genotype lb infection following transplantation: relationship with rejection episodes. Hepatology 29: 250-256.

6. Sanchez-Fueyo A, Restrepo JC, Quinto L, Bruguera M, Grande L, et al. (2002) Impact of the recurrence of hepatitis $\mathrm{C}$ virus infection after liver transplantation on the long-term viability of the graft. Transplantation 73: 56-63.

7. Velidedeoglu E, Mange KC, Frank A, Abt P, Desai NM, et al. (2004) Factors differentially correlated with the outcome of liver transplantation in hcv+ and HCV- recipients. Transplantation 77: 1834-1842.

8. Gordon FD, Kwo P, Vargas HE (2009) Treatment of hepatitis C in liver transplant recipients. Liver Transpl 15: 126-135.

9. Terrault NA (2008) Hepatitis C therapy before and after liver transplantation. Liver Transpl 14 Suppl 2: S58-66. factors proved to be statistically significant predictors of withdrawal from the treatment protocol. As patients withdrew from the treatment for diverse reasons, it would be difficult to predict each adverse event before the initiation of interferon therapy. Therefore, careful follow-up during the treatment procedure is important for early detection of adverse events and to prevent progression to severe complications.

In this study, the final outcomes of the treatment including standard interferon plus ribavirin and peginterferon plus ribavirin were analyzed. Difference of the efficacy between standard interferon and peginterferon might affect the results of our present study. We predicted that patients who had virological response to standard interferon would also show the same response to peginterferon, because it is reported that the efficacy of peginterferon plus ribavirin is higher than that of standard interferon plus ribavirin [44,48]. Accordingly, the patients who achieved SVR by standard interferon were included in the present study. On the other hand, all nonresponders and all patients who relapsed by standard interferon plus ribavirin were retreated with peginterferon plus ribavirin, and we analyzed the final outcomes of the peginterferon plus ribavirin therapy. Therefore, we conclude that the difference of treatment regimen has little influence on our results.

In conclusion, SVR to antiviral therapy in patients with recurrent hepatitis $\mathrm{C}$ after LDLT is predictable before transplant by serum HCV-RNA level and HCV genotype. In addition, patients who undergo ABO-incompatible LDLT appear to have a better VR to interferon therapy after liver transplantation. Mechanisms underlying these interesting results are unknown at present, but these findings are likely to be useful for improved clinical assessment of patients with hepatitis $\mathrm{C}$ after liver transplantation, and could lead to development of new strategies for better outcomes in LDLT recipients with the HCV genotype 1 and/or a higher pretransplant viral load.

\section{Author Contributions}

Conceived and designed the experiments: YU HM. Performed the experiments: YU TK YO KO AY KH YF AMH HH HM. Analyzed the data: YU ST. Contributed reagents/materials/analysis tools: YU TK YO KO AY KH YF AMH HH HM. Wrote the paper: YU HM SU TC.

10. Berenguer M (2008) Systematic review of the treatment of established recurrent hepatitis $\mathrm{C}$ with pegylated interferon in combination with ribavirin. J Hepatol 49: 274-287.

11. Berardi S, Lodato F, Gramenzi A, D’Errico A, Lenzi M, et al. (2007) High incidence of allograft dysfunction in liver transplanted patients treated with pegylated-interferon alpha- $2 b$ and ribavirin for hepatitis $\mathrm{C}$ recurrence: possible de novo autoimmune hepatitis? Gut 56: 237-242.

12. Fernandez I, Ulloa E, Colina F, Abradelo M, Jimenez C, et al. (2009) Incidence, risk factors, and outcome of chronic rejection during antiviral therapy for posttransplant recurrent hepatitis C. Liver Transpl 15: 948-955.

13. Stanca CM, Fiel MI, Kontorinis N, Agarwal K, Emre S, et al. (2007) Chronic ductopenic rejection in patients with recurrent hepatitis $\mathrm{C}$ virus treated with pegylated interferon alfa-2a and ribavirin. Transplantation 84: 180-186.

14. Berenguer M, Palau A, Fernandez A, Benlloch S, Aguilera V, et al. (2006) Efficacy, predictors of response, and potential risks associated with antiviral therapy in liver transplant recipients with recurrent hepatitis C. Liver Transpl 12: $1067-1076$.

15. Carrion JA, Navasa M, Garcia-Retortillo M, Garcia-Pagan JC, Crespo G, et al. (2007) Efficacy of antiviral therapy on hepatitis C recurrence after liver transplantation: a randomized controlled study. Gastroenterology 132: 17461756 .

16. Neumann U, Puhl G, Bahra M, Berg T, Langrehr JM, et al. (2006) Treatment of patients with recurrent hepatitis $\mathrm{C}$ after liver transplantation with peginterferon alfa-2B plus ribavirin. Transplantation 82: 43-47.

17. Oton E, Barcena R, Moreno-Planas JM, Cuervas-Mons V, Moreno-Zamora A, et al. (2006) Hepatitis C recurrence after liver transplantation: Viral and 
histologic response to full-dose PEG-interferon and ribavirin. Am J Transplant 6: 2348-2355.

18. Picciotto FP, Tritto G, Lanza AG, Addario L, De Luca M, et al. (2007) Sustained virological response to antiviral therapy reduces mortality in HCV reinfection after liver transplantation. J Hepatol 46: 459-465.

19. Rodriguez-Luna H, Khatib A, Sharma P, De Petris G, Williams JW, et al. (2004) Treatment of recurrent hepatitis C infection after liver transplantation with combination of pegylated interferon alpha2b and ribavirin: an open-label series. Transplantation 77: 190-194.

20. Sharma P, Marrero JA, Fontana RJ, Greenson JK, Conjeevaram H, et al. (2007) Sustained virologic response to therapy of recurrent hepatitis $\mathrm{C}$ after liver transplantation is related to early virologic response and dose adherence. Liver Transpl 13: 1100-1108.

21. Bacon BR, Gordon SC, Lawitz E, Marcellin P, Vierling JM, et al. (2011) Boceprevir for previously treated chronic HCV genotype 1 infection. N Engl J Med 364: 1207-1217.

22. Jacobson IM, McHutchison JG, Dusheiko G, Di Bisceglie AM, Reddy KR, et al. (2011) Telaprevir for previously untreated chronic hepatitis $\mathrm{C}$ virus infection. N Engl J Med 364: 2405-2416.

23. Poordad F, McCone J, Jr., Bacon BR, Bruno S, Manns MP, et al. (2011) Boceprevir for untreated chronic HCV genotype 1 infection. N Engl J Med 364: 1195-1206.

24. Zeuzem S, Andreone P, Pol S, Lawitz E, Diago M, et al. (2011) Telaprevir for retreatment of HCV infection. N Engl J Med 364: 2417-2428.

25. Garg V, van Heeswijk R, Lee JE, Alves K, Nadkarni P, et al. (2011) Effect of telaprevir on the pharmacokinetics of cyclosporine and tacrolimus. Hepatology 54: $20-27$.

26. Ge D, Fellay J, Thompson AJ, Simon JS, Shianna KV, et al. (2009) Genetic variation in IL28B predicts hepatitis C treatment-induced viral clearance. Nature 461: 399-401.

27. Suppiah V, Moldovan M, Ahlenstiel G, Berg T, Weltman M, et al. (2009) IL28B is associated with response to chronic hepatitis $\mathrm{C}$ interferon-alpha and ribavirin therapy. Nat Genet 41: 1100-1104.

28. Tanaka Y, Nishida N, Sugiyama M, Kurosaki M, Matsuura K, et al. (2009) Genome-wide association of IL28B with response to pegylated interferon-alpha and ribavirin therapy for chronic hepatitis C. Nat Genet 41: 1105-1109.

29. Charlton MR, Thompson A, Veldt BJ, Watt K, Tillmann H, et al. (2011) Interleukin-28B polymorphisms are associated with histological recurrence and treatment response following liver transplantation in patients with hepatitis $\mathrm{C}$ virus infection. Hepatology 53: 317-324.

30. Fukuhara T, Taketomi A, Motomura T, Okano S, Ninomiya A, et al. (2010) Variants in IL28B in liver recipients and donors correlate with response to peginterferon and ribavirin therapy for recurrent hepatitis C. Gastroenterology 139: 1577-1585, 1585 e1571-1573.

31. Akuta N, Suzuki F, Sezaki H, Suzuki Y, Hosaka T, et al. (2005) Association of amino acid substitution pattern in core protein of hepatitis $\mathrm{C}$ virus genotype $1 \mathrm{~b}$ high viral load and non-virological response to interferon-ribavirin combination therapy. Intervirology 48: 372-380.

32. Enomoto N, Sakuma I, Asahina Y, Kurosaki M, Murakami T, et al. (1996) Mutations in the nonstructural protein $5 \mathrm{~A}$ gene and response to interferon in patients with chronic hepatitis C virus 1b infection. N Engl J Med 334: 77-81.
33. Fukuhara T, Taketomi A, Okano S, Ikegami T, Soejima Y, et al. (2010) Mutations in hepatitis $\mathrm{C}$ virus genotype $1 \mathrm{~b}$ and the sensitivity of interferonribavirin therapy after liver transplantation. J Hepatol 52: 672-680.

34. Ueda Y, Takada Y, Haga H, Nabeshima M, Marusawa H, et al. (2008) Limited benefit of biochemical response to combination therapy for patients with recurrent hepatitis $\mathrm{C}$ after living-donor liver transplantation. Transplantation 85: 855-862.

35. Ueda Y, Takada Y, Marusawa H, Egawa H, Uemoto S, et al. (2010) Individualized extension of pegylated interferon plus ribavirin therapy for recurrent hepatitis $\mathrm{C}$ genotype $1 \mathrm{~b}$ after living-donor liver transplantation. Transplantation 90: 661-665.

36. Ueda Y, Marusawa H, Kaido T, Ogura Y, Oike F, et al. (2010) Effect of maintenance therapy with low-dose peginterferon for recurrent hepatitis $\mathrm{C}$ after living donor liver transplantation. J Viral Hepat.

37. Bedossa P, Poynard T (1996) An algorithm for the grading of activity in chronic hepatitis C. The METAVIR Cooperative Study Group. Hepatology 24: 289 293.

38. Poynard T, Bedossa P, Opolon P (1997) Natural history of liver fibrosis progression in patients with chronic hepatitis C. The OBSVIRC, METAVIR, CLINIVIR, and DOSVIRC groups. Lancet 349: 825-832.

39. Raut V, Mori A, Kaido T, Ogura Y, Taku I, et al. (2012) Splenectomy does not offer immunological benefits in ABO-incompatible liver transplantation with a preoperative rituximab. Transplantation 93: 99-105.

40. Ohno O, Mizokami M, Wu RR, Saleh MG, Ohba K, et al. (1997) New hepatitis $\mathrm{C}$ virus (HCV) genotyping system that allows for identification of HCV genotypes 1a, 1b, 2a, 2b, 3a, 3b, 4, 5a, and 6a. J Clin Microbiol 35: 201-207.

41. Fried MW, Shiffman ML, Reddy KR, Smith C, Marinos G, et al. (2002) Peginterferon alfa-2a plus ribavirin for chronic hepatitis $\mathrm{C}$ virus infection. N Engl J Med 347: 975-982.

42. Ghany MG, Strader DB, Thomas DL, Seeff LB (2009) Diagnosis, management, and treatment of hepatitis C: an update. Hepatology 49: 1335-1374.

43. Hadziyannis SJ, Sette H, Jr, Morgan TR, Balan V, Diago M, et al. (2004) Peginterferon-alpha2a and ribavirin combination therapy in chronic hepatitis C: a randomized study of treatment duration and ribavirin dose. Ann Intern Med 140: $346-355$

44. Manns MP, McHutchison JG, Gordon SC, Rustgi VK, Shiffman M, et al. (2001) Peginterferon alfa-2b plus ribavirin compared with interferon alfa-2b plus ribavirin for initial treatment of chronic hepatitis C: a randomised trial. Lancet 358: 958-965.

45. Thompson AJ, Muir AJ, Sulkowski MS, Ge D, Fellay J, et al. (2010) Interleukin$28 \mathrm{~B}$ polymorphism improves viral kinetics and is the strongest pretreatment predictor of sustained virologic response in genotype 1 hepatitis C virus. Gastroenterology 139: 120-129 e118.

46. Egawa H, Teramukai S, Haga H, Tanabe M, Fukushima M, et al. (2008) Present status of ABO-incompatible living donor liver transplantation in Japan. Hepatology 47: 143-152.

47. El-Shamy A, Nagano-Fujii M, Sasase N, Imoto S, Kim SR, et al. (2008) Sequence variation in hepatitis $\mathrm{C}$ virus nonstructural protein $5 \mathrm{~A}$ predicts clinical outcome of pegylated interferon/ribavirin combination therapy. Hepatology 48: $38-47$.

48. Triantos C, Samonakis D, Stigliano R, Thalheimer U, Patch D, et al. (2005) Liver transplantation and hepatitis $\mathrm{C}$ virus: systematic review of antiviral therapy. Transplantation 79: 261-268. 